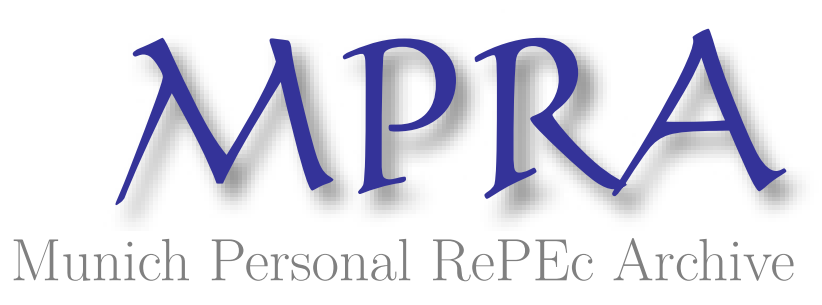

\title{
The Reverse Wage Gap among Educated White and Black Women
}

Houseworth, Christina and Fisher, Jonathan

20 January 2011

Online at https://mpra.ub.uni-muenchen.de/35827/

MPRA Paper No. 35827, posted 28 Aug 2012 10:08 UTC 


\section{The Reverse Wage Gap among Educated White and Black Women}

Jonathan D. Fisher*

New York Census Research Data Center

School of Public Affairs, Baruch College

135 East 22nd Street, Box D-901

New York, NY 10010

jonathan.fisher@census.gov
Christina A. Houseworth

Litigation Analytics, Inc.

370 Lexington Avenue

Suite 1802

New York, NY 10017

chouseworth@litigationanalytics.com

\footnotetext{
* This research was conducted while Jonathan Fisher was working with Litigation Analytics, Inc.
} 


\title{
Key Words
}

Human capital, differential demand and supply for schooling, wage gaps

\begin{abstract}
Using the 2004 National Sample Survey of Registered Nurses and the 2004-2005 American Community Surveys, we estimate the black-white wage gap among females with at least some college education. We find that black female nurses earn 9 percent more at the mean and median than white female nurses, controlling for selection into nursing employment. Among K-12 teachers, black females earn 7 percent more than white females at the median. There is no blackwhite wage gap among all women with a bachelor's degree. Differences in opportunities for education and marriage between white and black women may explain why highly educated black females earn on par with highly educated white females.
\end{abstract}

\author{
Abbreviations \\ ACS - American Community Survey \\ NSSRN - National Sample Survey of Registered Nurses \\ OLS - Ordinary Least Squares
}




\section{Introduction}

Differences in socioeconomic status by race persist in the United States, although there has been some convergence over time. Blacks have, on average, lower wealth, income, wages, and levels of human capital than whites. These differences can be explained through differences in opportunities, individual characteristics and discrimination. There is a large literature that attempts to explain wage differentials with the latter two explanations. Opportunities may differ by race affecting, among other things, the supply of education, the demand for education, and marriage markets. These differences will affect investment in human capital. For instance, blacks attend lower quality schools (Alliance for Excellent Education, 2008, and Orfield and Lee, 2005), which will affect the demand for higher education. Further, black women face a substantially tighter marriage market, which may induce a higher demand for education. Differences in opportunities affect an individual's decision to obtain higher levels of education, occupation choice, and the decision to marry, which in turn, affect wages. It has been found that differences in marriage outcomes between black and white women can affect our perception of the racial wage gap (Neal, 2004).

Given that there are different characteristics and opportunities between blacks and whites, and that these differences affect wages, shouldn't we expect wage differentials to differ by education level? An examination of the characteristics of educated women is the first step in identifying how differences in opportunities, such as access to education and the marriage market, affect the racial wage gap among women. Using the 2004 National Sample Survey of Registered Nurses (NSSRN), registered nurses are used to examine the black/white wage gap among educated women. 
The restriction to registered nurses does not limit the interpretations of the results found in this research. Rather, the findings here can be applied to all women with higher levels of education. Registered nurses were chosen because of the specific characteristics that ease in the interpretation of the racial wage gap among women. More specifically, registered nurses were chosen because of the education requirement, because over $90 \%$ are female, and because we can control for selection into employment with the NSSRN. These specific occupational characteristics allow for the examination of a highly educated group of women in an occupation that has few males. Therefore, the examination is not complicated by issues related to the gender wage gap. The NSSRN provides earnings information regardless of employment, and, therefore, can be used to control for selection into employment. In addition, the NSSRN provides other useful information not found in economy-wide data, such as information on the financing of the individual's nursing education. The results are then expanded beyond nurses by examining the racial wage gap among all women with higher education using the 2004-2005 American Community Surveys (ACS).

This paper differs from previous studies by focusing on highly educated women while controlling for selection into employment. While initially nurses are examined, the analysis is extended to K-12 teachers, and then to all women with at least some college education. The same reasoning discussed above for the examination of nurses can be applied to teachers. K-12 teaching is also primarily female, and spread out across the country. Most importantly, K-12 teaching also requires higher levels of education for the most part. The reverse wage gap among nurses is emblematic of wider trends and should begin an academic discussion of deeper underlying factors which affect individual's wages. This paper provides a thorough discussion 
of the important factors and markets that contribute to differences in wages among black and white women.

\section{Wage Gaps}

Studies have found that controlling for education and experience among the highly educated can explain much of the wage gap. Black, Haviland, Sanders \& Taylor (2006) find that the observed racial wage gap among college-educated men born outside the South was approximately zero. For black men born in the South and those born outside the South but born to poorly educated parents, the wage gap is related to the lower quality education they receive. O'Neill and O'Neill (2005) conclude that differences in the quantity of education and the quality of skills account for most of the wage gap between white and black men and women. Anderson and Shapiro's (1996) findings suggest that highly educated black women suffer less racial labor market discrimination than lower educated black women. Jacobson, Olsen, Rice, Sweetland \& Ralph (2001) show that for women with similar levels of education, blacks earn as much, or more, than whites. Black, Haviland, Sanders \& Taylor (2008) find that controlling for observables for Asian and Hispanic women with high labor force attachment and high levels of education renders the gender wage gap relative to white men essentially zero. The same study shows that when experience is not controlled for, black women earn more than white women. The reverse is found when controlling for experience. None of the latter four papers that focus on women, however, control directly for selection into employment.

In addition to differences in observable characteristics, selection into employment can help to explain wage gaps. The original Oaxaca-Blinder technique decomposes the wage difference between those who are working and receiving a wage. If selection into employment is 
not random, then the observed wage gap among those who are working is likely to be a biased measure of the population wage gap.

Selection into employment is particularly important when examining the wage gap among black and white women. Among white women, those not employed are more likely to be married with children, and they may choose not to work for pay. Positive assortative mating implies that high ability marry high ability, meaning that the white women who are not employed could garner a high wage if working. Thus, white married females who are not employed cause observed wages for white women to be biased downward. Neal (2004) finds that black women who are not employed are more likely to be single mothers, and receiving welfare may be a better option than working. Therefore, black women who do not participate in the labor force are those with relatively low earnings, which biases observed wages for black women upward. If observed wages for white women are biased downward and observed wages for black women are biased upward, the observed wage gap between employed white and black women is too small. Selection into employment may explain why O’Neill and O’Neill (2005), Anderson and Shapiro (1996), and Jacobsen, Olsen, Rice, Sweetland \& Ralph (2001) find that the racial wage gap among educated women is relatively small. They do not control for selection, therefore, black female wages may be overstated relative to white female wages.

Neal (2004) considers selection patterns into employment between white and black women. Using data from the 1990 National Longitudinal Survey of Youth, he imputes wages for those not employed. Using the imputed wage technique, Neal finds that the wage gap increases by almost $60 \%$.

In addition to selection into employment, selection into post-secondary education may help to explain differences in wages between groups, but these selection issues may work in the 
opposite direction. If the costs of attending post-secondary schooling are higher for blacks, then the blacks who choose to attend post-secondary may have higher unobserved ability than whites who choose to attend post-secondary schooling. It follows that, absent discrimination in the labor market, blacks who graduate from college should have a higher wage than whites who graduate from college. Jacobson et al (2001) find that for young adults with similar levels of prior educational achievement, blacks are more likely to attend college than whites. Among those in college with similar levels of ability (reading and mathematics test scores), blacks are just as likely, or more likely, to complete college as whites. Urzua (2008) finds that for the same ability level, blacks have higher levels of schooling. It is unclear what is driving this result. It could be that it takes more schooling to get the same level of ability. It may also be that for the same level of ability, blacks have a lower supply of funds and have more of an incentive to perform well in school. Therefore, they may be more likely to complete their degree, or continue with their education than their white counterparts. These results may indicate that blacks who choose to attend college are different than their white counterparts.

Finally, different marriage market conditions between black and white women will generate different levels of investment in human capital. Lichter, LeClere, and McLaughlin (1991) find that for every three black unmarried women in their 20s, there is roughly only one unmarried man with earnings above the poverty threshold. Because black women have a poorer marriage market, they may be more likely to invest in higher levels of human capital.

\section{Data and Empirical Methodology}

\subsubsection{National Sample Survey of Registered Nurses (NSSRN)}

To estimate the black-white female wage gap among registered nurses, we use the National Sample Survey of Registered Nurses (NSSRN), which is a national sample of 
individuals holding a registered nurse license and is conducted by the U.S. Department of Health and Human Services. The sample is derived from state registries of those holding a registered nurse license. Smaller states are oversampled to aid in estimating workforce supply conditions for each state.

The survey began in 1977 and was conducted again in 1980 and every four years since. We use the 2004 survey for our main analysis. Two important variables are included only in 2004, years of nursing experience and urban/rural status. The response rate in 2004 was 70.5 percent, for a total of 35,724 respondents. Respondents are asked questions regarding formal education and additional training and certificates received. When referring to educational attainment, we use the highest nursing degree earned. Some have higher degrees in a nonnursing field. Demographic information includes gender, race, year of birth, marital status, presence of children, and household income.

An individual stays in the sample frame as long as she maintains an active license. Thus, the sample includes all individuals, regardless of employment status. The survey provides a wide range of information for those not utilizing their license. Respondents that are not employed as nurses are asked if they are unemployed or employed outside of nursing, and their reason for leaving nursing. Information on current job title, average hours worked per week, and gross annual earnings at the current job is provided for those employed outside of nursing. The only information available for the unemployed is whether the individual is seeking employment in nursing.

For those employed in nursing, detailed job characteristics are gathered, including title, type of unit (e.g. emergency room), and setting (e.g. hospital). To estimate wages for those employed in nursing, we use questions on the financing of their R.N. education, number of 
weeks normally worked per year, hours worked in the last full workweek, and current gross annual earnings including overtime and bonus income. All three questions refer only to the individual's principal nursing position.

\subsubsection{American Community Survey (ACS)}

We use the 2004 and 2005 American Community Surveys (ACS) to examine the racial wage gap among females. Conducted by the U.S. Census Bureau, the ACS replaces the Decennial Census Long-Form. The 2004 ACS had over 568,000 respondents, and the 2005 ACS had over 1.9 million respondents. The large sample allows us to look at wage gaps by occupation using just two years of data.

Questions regarding earnings, hours, and weeks are similar to other national surveys and to the NSSRN. Earnings are for the previous twelve months; hours are the usual hours worked per week in the last twelve months, and weeks are the number of weeks worked in the past twelve months.

\subsection{Empirical Methodology}

We estimate the hourly wage as the gross earnings divided by the product of hours and weeks worked. The estimated hourly wage is censored at the first and ninety-ninth percentiles to control for outliers.

To estimate the black-white female wage gap among nurses, we follow the basic methodology of Blinder (1973) and Oaxaca (1973). Separate log wage models are run for black females and white females.

$$
\log \left(W_{i}\right)=X_{i}^{\prime} \beta+u_{i}
$$

$W_{i}$ equals the hourly wage rate for individual $i ; X_{i}$ is a vector of individual characteristics; $\beta$ is a vector of coefficients; and, $u_{i}$ is a disturbance term. The model includes four dummy variables 
for education (associates degree, diploma degree, bachelor's degree, and master's degree or higher), ${ }^{1}$ three dummy variables for marital status (married, single, and divorced/separated/widowed), three dummy variables for children (child less than six-years old in the home, child aged 6-17, and no child under 17 in the home), years of experience in nursing and its square, ${ }^{2}$ whether the nurse had help from family or other relatives in financing her R.N. education, four region variables, four urban status variables (urban, large rural, small rural, and isolated rural), ${ }^{3}$ whether the individual was employed in nursing last year, and three dummy variables for mobility (moved once to a different state since obtaining license, moved more than once, and has not moved between states).

The basic models exclude those who are not working in nursing at the time of the survey. Thus it excludes those employed outside of nursing and those not working. Neal (2004) showed, however, that ignoring females who are not working biases the black-white female wage gap.

We employ two methods to address potential selection into employment. The first is the standard Heckman correction method for selection bias. Heckman (1979) accounts for selection by first estimating an equation determining the probability of labor force participation and then using the computed hazard rate variable in the wage equation. This method has been criticized because it requires specific functional form restrictions and requires a variable that affects the decision to work but not the wage. A typical instrument in this literature, especially for women, is household income. Women who have spouses with high earnings may be less likely to work outside the home, and their spouse's earnings may not affect her potential wage. The NSSRN

\footnotetext{
${ }^{1}$ To take the exam to become a registered nurse, the individual must complete a bachelor's degree in nursing from a 4-year college, an associate's degree in nursing from a 2-year college, or a three-year diploma program through a hospital. A graduate degree in nursing is not an entry-level degree.

${ }^{2}$ The survey asks how many years the respondent has worked at least half the year since receiving her registered nurse license.

${ }^{3}$ The NSSRN creates these variables based on the rural-urban commuting area codes developed by the U.S Department of Agriculture.
} 
includes a bracketed variable for total household income. We assign the mid-point of the bracket and then subtract the respondent's total earnings to arrive at non-nursing household income.

The second method follows Neal (2004) and imputes a wage for those not employed in nursing. We create race, education, marital status, and children status cells and assign the median of that cell to all women in that cell who do not have an observed wage. Because we are imputing wages for a specific occupation with strict licensing requirements, this imputation method should be more accurate than when applied to a sample drawn from all occupations, such as is done in Neal (2004).

For those employed outside of nursing, we ignore their wage rate from their non-nursing employment, as we are interested in the nursing wage gap. Therefore, we estimate the wage these women would receive if they worked in nursing as a proper measure of the nursing racial wage gap.

\section{Results}

Basic summary statistics are presented to describe the race wage gap among female nurses, labor force participation rates and mean values for independent variables. Empirical results include an Ordinary Least Squares (OLS) using the Blinder-Oaxaca decomposition, and then we discuss decomposition results when correcting for selection into employment. In all decompositions, the reference group is black females.

\subsection{Wage Gap and Descriptive Statistics}

Table 1 presents the mean and median wage gap for nurses in the NSSRN. Mean and median earnings for black female nurses are 9 percent higher than for white female nurses in 2004. From now on, we discuss and present the wage gap as black wages over white wages, 
such that a gap of 1.09 means that blacks earn 9 percent more than whites, and an increase (decrease) in the wage gap means the gap widens (narrows) in favor of blacks.

One major concern regarding wage differentials is selection into employment. Neal (2004) finds that the female racial wage gap is 60 percent larger in favor of whites when controlling for selection into employment. White women who are not employed are more likely to be in high income households while their black counterparts are more likely to be single mothers.

In the sample of registered nurses, 77.8 percent of black women are employed in nursing and an additional 5.2 percent are employed outside of nursing (Table 2). Similarly, 77.2 percent of white women are employed in nursing and an additional 7.6 percent are employed outside of nursing. Among those not employed, 5.8 percent of black women are not in the labor force, while a higher percentage of white women, 8.5 percent, are not in the labor force. Table 2 does not appear to conform to the narrative found in Neal (2004) regarding labor force participation rates. The modal black woman not employed in nursing is married with a child under age 18 in the home, while the smallest group of black women not employed in nursing are unmarried with children under age 18 in the home. In addition, the labor force participation rate for non-married black women with children is just over 94 percent. The corresponding labor force participation rate for white women is 93 percent. White married women with no children in the home are about 2 percentage points more likely to be out of the labor force than their black counterparts; however, the difference is not large compared to the percentage of all white women who are out of the labor force. Thus, even when we control for selection into employment below, we should not expect the results to change dramatically. 
The mean wage gap decreases as education increases, and at the median, the wage gap is essentially zero for those with a graduate degree (Table 1). Table 3 shows that among registered nurses, regardless of employment status, black females have higher levels of education. Over 52 percent of black females have a bachelor's or graduate degree in nursing, while 48 percent of white females have a similar level of education. Nationally, a higher percentage of white women have a bachelor's degree or greater. Over 26 percent of white women and 18.5 percent of all black women in 2004 had at least a bachelor's degree. ${ }^{4}$ Table 3 could suggest that part of the reason blacks earn higher wages in nursing is their higher education.

White females are more likely to be married, more likely to have resources from their family help pay for their education, less likely to live in the south, and less likely to work in an urban area. As wages are generally higher in urban areas, a higher percentage of black nurses working in urban areas may explain why blacks earn more than whites on average. The opposite is true for south as wages are generally lower in the south and a higher percentage of blacks live in the south.

\subsection{OLS Results}

Table 4 presents the basic results using Ordinary Least Squares, not correcting for potential selection bias. In this full specification, we include all variables that might be related to wages in order to determine whether we can explain away the observed reverse wage gap. Some variables, such as whether you worked as a nurse last year, are related to the structure of wages. For example, a reverse wage gap may make black nurses more likely to work last year because of the wage premium they are receiving relative to white nurses. Because we are primarily interested in whether we can explain away the observed reverse wage gap, an intuitive explanation of the effects of these potentially endogenous variables is not within the scope of this

\footnotetext{
${ }^{4}$ http://www.census.gov/compendia/statab/tables/09s0222.pdf
} 
paper. However in Table 5 discussed below, we do show how the wage decomposition changes under alternate specifications to determine whether our conclusions depend on the inclusion of these variables. In the discussion below, we focus on the variables that affect the wage gap.

A Chow/Wald test indicates that the coefficients differ between blacks and whites. Therefore, models are run separately for blacks and whites, with the Blinder-Oaxaca decomposition shown at the bottom of the table. The coefficients match expectations.

The Blinder-Oaxaca decomposition shows that black female nurses earn 8.1 percent more than white female nurses. The wage gap is broken down into two components: the portion due to differing endowments of the independent variables, and the portion unexplained. Table 4 shows that if whites were given the endowments of blacks then the gap would decrease by 12.2 percent. This means, however, that blacks still earn approximately 7.1 percent more when controlling for observable differences, using a standard wage decomposition technique.

For most variables, the coefficients match signs between blacks and whites. There are differences between white and black coefficients in regards to the variables marital status, associate degree, and very mobile. However, the coefficients are either statistically insignificant for both or are only statistically significant for one group.

The benchmark group for the education variables is those with a diploma only. The premium for having a bachelor's degree is relatively small, just 4.4 percent for whites and 5.8 percent for blacks. The graduate premium is significantly higher at 23.6 percent and 20.7 percent, respectively. Education variables are a large determinant of the wage gap. Blacks have a higher return to holding a bachelor's degree, which explains 7.5 percent of the wage gap. Blacks are also more likely to have a bachelor's degree. If white women received the higher return to a bachelor's degree as blacks and obtained this degree at the same rate, the wage gap 
would decrease by 9.8 percent. Adding the effect of all of the education variables indicates that if whites had the same return as black females and the same likelihoods, the wage gap would decrease by 20.1 percent.

Black women are less likely to live in rural areas. If the same percentage of whites lived in rural areas as blacks, the wage gap would narrow by 39.3 percent. However, blacks have a higher penalty than whites for living in a rural area. If whites were to receive the wage penalty that blacks receive for living in rural areas, the wage gap would widen by 27.7 percent. Combining these effects, the four rural/urban variables together shrink the wage gap by 11.6 percent.

Blacks are less likely to live in the Northeast and West but earn a higher return to living in those regions than whites. Similarly, blacks are more likely to live in the South but receive a lower return than whites to living in the South compared to living in the Midwest. The net effect of the region variables widens the wage gap. Because blacks are twice as likely to live in the South as whites and because the wages in the South are lower than in the Northeast or West, giving whites the region endowments of blacks increases the wage gap. It appears that the penalty to living in the South for black women is large enough to counter the gain in other regions.

Table 5 presents sparser specifications. The first specification uses the only variable that is plausibly fixed before job market decisions are made - whether the nurse used money from family members to help pay for her R.N. education. We use this variable as a proxy for parental wealth and unobservable parental characteristics that may be correlated with education and ability. As shown in Table 3, whites were more likely to have help from their families. Using just family resources, the wage gap actually widens in favor of blacks. The next specification 
includes education, marital status, and the presence of children. The results again indicate that the wage gap widens when only controlling for these variables.

\subsection{Correcting for Selection into Nursing Employment}

Black women may have higher wages even controlling for observables because selection into employment is not being controlled for. As Neal (2004) finds for females as a whole, accounting for selection raises the average wage of whites and lowers the average wage of blacks. However, the sample used in Neal (2004) is that of black and white women in all occupations and education levels, where differences are due in large part to low wage black females being out of the labor force. Women, such as registered nurses, who have invested in human capital with schooling beyond high school and with a specialized license are less likely to have low wages than women as a whole. Government assistance is not likely to be an optimal outcome considering the income they could earn as a nurse. This should also be true for more educated women as a whole, even outside of nursing.

A more applicable portion of Neal's discussion of selection concerns married white women and positive assortative mating. Selection is controlled for in two ways. ${ }^{5}$ A standard Heckman selection correction is used where non-nursing income (total household income less earnings from the registered nurse) is used as an instrument for nursing employment. This income measure is used under the assumption that husband's earnings will affect the decision to work but not the wage received. ${ }^{6}$ The second sample selection method follows Neal (2004) by imputing wages for those who are not employed in nursing. To impute wages, cells for race, education, marital status, and presence of children in the home are used. The median of each cell

\footnotetext{
${ }^{5}$ Imputation and the Heckman selection both are problematic, and previous research has shown that the BlinderOaxaca decomposition can be sensitive to the selection correction method (Beblo, Beninger, Heinze \& Laisney 2003). Including both methods provides evidence that the results are robust to the two models.

${ }^{6}$ This is a questionable assumption if not just for the fact that we argue that there is positive selection in marriage. In addition, total household income is noisy because it is reported in brackets.
} 
for those who are employed in nursing are used as the imputed wage for those who are not employed in nursing.

Because we are only interested in whether selection into employment affects the wage gap, regression results for these methods are not presented but are available upon request. Instead, Table 5 displays the portion of the wage gap explained by our various techniques. First, the results from Table 4 using OLS are presented, showing that 23.6 percent of the wage gap is explained by observables without correcting for selection into employment. Using the Heckman selection method, the portion of the wage gap that is explained actually decreases to 5.5 percent. The results indicate that there is negative selection for both blacks and whites, suggesting that unobserved factors that make employment in nursing more likely to be associated with lower wages. Neal (2004) hypothesizes that selection into employment differs between blacks and whites, which is inconsistent with these results. However, Neal analyzes females regardless of education.

Only 19.6 percent of the wage is explained when using imputed wages for those who are not employed in nursing. Regardless of method for correcting for selection into employment, the wage gap is not explained by differences in observables. See Appendix B for results with variables including job setting (e.g. hospital), occupation (e.g. staff nurse), union status, ${ }^{7}$ prior health care experience, additional training, and other variables which are important determinants of nurse earnings. Again, less than 5 percent of the wage gap is explained in a kitchen sink-type regression. Thus, the wage gap among those that have invested in human capital cannot be as easily explained by differences in employment as was shown in Neal (2004). ${ }^{8}$

\footnotetext{
${ }^{7}$ The non-union median wage gap is 8.9 percent, while the union wage gap is 6.9 percent.

${ }^{8}$ Research has shown that the Blinder-Oaxaca decomposition requires parametric assumptions that may not be supportable. Black et al. (2006) present a non-parametric wage decomposition that we utilized for our sample. The
} 


\section{Discussion}

Observable variables examined do not explain why black female nurses earn 9 percent more than white female nurses. Education and urban status explain a portion of this gap, but the unexplained portion of the gap remains large. A narrowing and even reversal of the female black-white wage gap has been documented in earlier literature (Neal and Johnson, 1996; Bollinger 2003), where selection into employment was not controlled for. Neal (2004) attributed the narrowing of the female black-white wage gap primarily to differing selection into employment by race. We do not find empirical evidence to support this hypothesis with our sample of nurses. Black female nurses earn a higher mean and median wage than white female nurses, even when controlling for selection. This section explores other factors that might explain the wage gap and presents evidence when possible. While we explore nurses in the first part of this section, many of the same arguments will apply to educated women as a whole. We focus on nurses because of the unique variables available in the NSSRN such as how the higher education was financed and actual labor market experience.

\subsection{Supply and Demand for Education}

Selection into employment is not the only possible explanation for a wage gap in favor of black females. There are differences between black and white women in labor force attachment, ability, supply and demand conditions for education, and marriage markets. Neal (2004) argues that, all else equal, black women may have higher average wages than white females because black females are more attached to the labor force. Therefore the observed wage for black females should be higher because of this additional human capital. The 2004 NSSRN includes information on the number of years the individual worked at least half the year in nursing. At

percent of the wage gap that was explained by differences in observables using the Black et al. decomposition is smaller than is seen in Table 5. Thus, we do not present these results here. 
the mean and median, black nurses have lower actual experience than whites (Table 3).

Additionally, for a given year of potential experience, black nurses have 0.64 years of actual experience, while white nurses have 0.69 years of actual experience for a given year of potential experience. Hence, the argument that black females are more attached to the labor force is not applicable for our sample of nurses.

The wage gap may also be explained through education. A defining characteristic of nursing is that it requires significant investment in human capital. To become a registered nurse, an individual is required to obtain at least two years of post-secondary education. Unlike the population as a whole, black females have more education than white females. As discussed above, this education differential in favor of blacks explains a portion of the wage gap. It is still unexplained why black nurses are more educated than white nurses.

In general, differences between whites and blacks in ability and in the supply and demand for education will affect the return to education, ${ }^{9}$ which in turn affects educational attainment and wages.

\subsubsection{Supply for Education}

Average incomes are lower for blacks and therefore black parents are less likely to be able to provide support for post-secondary education for their children (Black and Sufi, 2002). Thus, black women may be less likely to have family support for higher education. Cameron and Heckman (2001) and Carneiro and Heckman (2003) also argue that living in lower income households hinders the human capital accumulation of blacks. Caldwell (2009) finds that changes in affirmative action policies affect human capital accumulation, indicating that differences in perceived opportunities for education affect investment. Linsenmeier, Rosen, and Rouse (2002) find that black students were more sensitive to financial aid packages than whites,

\footnotetext{
${ }^{9}$ See Becker and Chiswick (1966) for a model of the supply and demand for education.
} 
suggesting that the ability to finance post-secondary education is a barrier to blacks. If family support is lower for black females, the supply of funds is lower, indicating a higher rate of return on the investment is needed for blacks to attend college, all else equal. For an individual to benefit from that additional education, the rate of return to that education should be larger. Therefore, the return to education should be higher for blacks. For a good discussion of the relationship between the return to education and the marginal benefit and marginal cost of education see Chiswick (1988).

The 2004 NSSRN survey provides information on the financing of the individual's nursing education. The categories listed are personal resources, family resources, employer tuition reimbursement plan, federal traineeship, and federal, state, local government, and nongovernment scholarships, grants, or loans. Black nurses are almost twice as likely to have financed their nursing education by loans or scholarships alone (24.6\% versus $12.4 \%$; Table 6 ), $34 \%$ less likely to have financed by self or family $(27.2 \%$ versus $41.4 \%)$, and almost twice as likely to be funded by their employer only $(2.5 \%$ versus $1.3 \%)$. The remaining $46 \%$ of black nurses and $45 \%$ of white nurses rely on some combination of these sources for their funding. Black nurses are less likely to rely solely on their family for financing their nursing education. Black nurses face a higher cost of nursing education if they are more likely to borrow to pay for their education.

Given that the cost of attending post-secondary schooling is higher on average for blacks than whites, for a given set of observable pre-market characteristics (e.g. AFQT as a proxy for ability), one would expect that the average black female who received post-secondary schooling would have higher unobservable skill than the average white female who received postsecondary schooling. An individual who faces more obstacles must have a strong reason to 
believe they will succeed in order for the investment to make sense a priori. This unobservable skill may be rewarded in the labor market through higher wages, but it may be unobservable to the econometrician.

\subsubsection{Demand for Education}

Additionally, the demand curves for education may be different between blacks and whites due to marriage market characteristics. "Marriageable" black men are in more limited supply, especially for highly educated black females, as black males have higher than average unemployment and incarceration rates, and lower than average levels of education, compared to both white males and black females. Black females, on average, have higher levels of education and are more likely to be employed than black males (Houseworth 2008). Further, two thirds of marriages between blacks and whites are between black men and white women, while black women have very low rates of racial intermarriage (The Journal of Blacks in Higher Education, 1997). Finally, non-black women are more likely to be married to black men if the black spouse is highly educated (Gullickson, 2006, Houseworth, 2008, Qian, 1997). Therefore, black females compete for an already limited number of "marriageable" black males with other racial groups, while at the same time their relevant marriage pool tends to exclude other racial groups.

With poorer marriage market prospects, black woman may invest more in their own careers. Gould and Paserman (2003) argue that higher wage inequality among white men may lead white women to invest more in their own education and work experience. Further, risk averse women may choose to work more because they are less able to diversify income risk through marriage. If the marriage market is worse for black women, then one would expect that these effects would be larger for black women as well. As a result, black females may be more likely to obtain higher levels of education in order to maximize future earnings. Seitz (2009) 
develops a dynamic equilibrium model where marriage and employment decisions are made simultaneously. However, this model does not consider the decision to obtain higher education.

Taking the risk averse argument a step further, because of a poorer marriage market, black females also may be more likely to choose an occupation that provides a steadier source of income, such as nursing. An individual may be less likely to choose an occupation with a high variance in earnings if the individual cannot diversify income risk through marriage. Therefore, high ability black women may be more likely to choose an occupation that has less income risk, such as nursing. There are chronic shortages of nurses, thereby insuring a demand for nurses. ${ }^{10}$

The effect of consumer discrimination on the wages of blacks may be less in an occupation such as nursing because the customers are also likely to be black. Hospitals, in general, serve local populations. As much as local areas are segregated, hospitals are segregated as well. Thus black nurses are less likely to face discrimination by customers if they work in areas where they live.

\subsubsection{Summary}

There may be several unobservable factors that suggest that the wages of black female nurses may be higher than the wages for white female nurses. Because the supply of funds for education is lower for blacks for the reasons listed above, the marginal benefit to education should also be higher for those blacks who choose higher education. Therefore blacks who choose higher education have higher unobserved ability than whites. Second, because of the poorer marriage market for black females, nursing as an occupation with steady demand and jobs spread throughout the country may attract high quality black females who are worried about the quality of the marriage market. These black women are choosing a more secure job in case they

\footnotetext{
${ }^{10}$ There were nursing shortages in the mid-1980s and late 1990s (Veneri, 1999). Auerbach, Beurhaus, and Staiger (2007) project nursing shortages to continue and worsen after 2016. Table 3 also supports this and shows that 56.6 of black nurses are married while 74.1 percent of white nurses are married.
} 
are not able to diversify income risk through marriage. Thus, nursing may be a more attractive occupation for high ability blacks.

However, these are all partial equilibrium arguments. A tendency towards a long-run equilibrium would imply that black females should observe this gap and enter into nursing. ${ }^{11}$ As more black females enter nursing, we might expect that lower quality black females will make the decision to enter into nursing. As lower quality black women enter into nursing, the wage gap between white and black females will narrow in favor of whites. Figure 1 presents the percent of nurses that are black females along with the black-white female nursing wage gap between 1980 and 2004, using the various years of the NSSRN. As predicted, black females went from 4.3 percent of nurses to 5.7 percent of nurses between 1980 and 2004, while the wage gap fell from blacks earnings 11.9 percent more to 8.8 percent more.

\subsection{Supporting Evidence}

Most of the discussion above regarding the wage gap between white and black females in nursing can be applied to all females. The differences between black and white nurses that explain the wage gap are likely to be similar to the female black-white wage gap as a whole. Specifically differences in labor force participation rates, ability, supply and demand conditions for education, and marriage markets among black and white women will be present in other occupations requiring higher education and among highly educated women as a whole.

K-12 teaching is also primarily female, and spread out across the country. Most importantly, K-12 teaching also requires higher levels of education for the most part. Descriptive statistics for black and white teachers are shown in Table 7. Black female teachers have slightly higher levels of potential experience than their white counterparts, where the

\footnotetext{
${ }^{11}$ Jones and Gates (2004) make a similar conjecture regarding male nurses. They find that male nurses earn more than female nurses and wonder whether this differential will lead to more men entering nursing.
} 
opposite is true for nurses in the ACS and NSSRN. Black females in both occupations are less likely to be married, more likely to be divorced, separated, widowed or single than white women. Black teachers are less likely to have a child in the home than white women, where the opposite is true for black nurses. Black nurses are more likely to have a bachelor's degree, while black teachers are slightly less likely. The characteristics of teachers suggest similar patterns among nurses and teachers. For example, black females in both occupations are less likely to be married, more likely to be divorced, separated, widowed or single than white women. A larger percentage of both black nurses and teachers have a graduate degree than white females. Regional patterns are similar for teachers and nurses. Black teachers also have higher earnings than their white counterparts. The median wages of black female K-12 teachers are about 7 percent higher than those of white females (Table 8) in the ACS, where black female nurses earn 8 percent more at the median in the ACS.

The wage gap results in Table 8 suggest that Neal's (2004) findings may be largely influenced by the high proportion of blacks with low levels of education. The importance of education in explaining the wage gap is further highlighted with the ACS data in Table 9. Ignoring education and occupation, black females earn 93 percent of the earnings of white females at the median, using the 2004-2005 ACS. Black females with a high school diploma or less earn 92 percent of the earnings of white females with the same level of education. Black and white females with a bachelor's degree earn about the same at the mean and median, while blacks with post-graduate degrees earn 108 percent of white females. Thus, the wage gap favors white females at lower levels of education and favors black females at higher levels.

Of course, the wage gap for higher levels of education may decrease in favor of white females (i.e., white females would earn more relative to blacks) when controlling for selection 
into employment. Black females with low levels of education are much less likely to be employed than their white counterparts; however, the reverse is true for higher levels of education (Table 9). Using the median of the race and education cell, wages were imputed following the method in Neal (2004). In results not presented in the table, imputed wages indicate that black females earn 83 percent of the earnings of white females at the median. When not controlling for selection, this figure is 93 percent.

These results suggest that education and selection into employment are keys to understanding the racial wage gap among females. Black and white women face very different supply and demand conditions for education. In addition, black women face a very different marriage market than those of white females, which may affect their decision to invest in a given amount of human capital.

If education is a key to the white-black female wage gap, then is education a similar key for men? Table 9 shows that it does not appear to be in the 2004-2005 ACS data. The wage gap stays constant across education levels. However, employment rates by education and race differ for men. Controlling for selection into employment may decrease the male wage gap as education increases, but it is not likely to approach what is seen among females. Highly educated black males will still earn considerably less than highly educated white males at the median.

\section{Conclusion}

This paper focuses on the racial wage gap among highly educated females. However, the restriction to registered nurses does not limit the significance of the results discussed above. Registered nurses were chosen because of the specific characteristics that ease in the interpretation of the racial wage gap among women. We present evidence that these findings can 
be applied to all women with higher levels of education. An examination of registered nurses finds that black female nurses earn 9 percent more than white female nurses. Contrary to existing research, this result holds when controlling for selection into employment.

Inequality of opportunities between white and black females may help to explain this reverse wage gap. The term "opportunities" is used broadly, as there may be differences in opportunities that arise from family background, education, marriage markets and others. Blacks are likely to have a lower supply for education and therefore in order to make the investment worthwhile, those who choose to attend post-secondary schooling are of higher average ability. Consequently, blacks who attend college may be of higher average ability than whites who attend post-secondary schooling. This unobserved ability is rewarded in the labor market. Less favorable marriage markets for blacks also affect the demand for education among blacks and may affect the occupational choices of black females. Women whose marriage prospects are less favorable will be more likely to invest in human capital. Both a higher demand curve and lower supply curve indicate a higher rate of return to education for black women.

As supporting evidence of these hypotheses, K-12 teachers are examined. Black females earn 7 percent more than white females in this occupation. Further, among all occupations, employed black females with at least a bachelor's degree earn more than employed white females with at least a bachelor's degree.

Corresponding to other research on racial wage inequality, our results indicate that education is a key determinant of wage gaps. Currently, 26.4 percent of white women have at least a college degree while only 18.5 percent of black women do. However, encouraging postsecondary education may not necessarily increase the relative wages of highly educated black females. As the percentage of black females who attend college increases, and unobserved 
ability is more equally distributed among the additional black college graduates, then it will reduce the relative wages of college-educated black females. Consider that as the percent of blacks has increased over time in nursing, the wage premium received by blacks has decreased, as shown in Figure 1. However, additional education certainly has non-wage benefits and likely would decrease the overall female racial wage gap.

The findings presented in this paper raise an important question in regards to differences in opportunities for education and marriage, and how they affect the educational and occupational choices of women. Some evidence is presented to support the theory that black women choose more stable occupations such as nursing and teaching because they have less favorable marriage market prospects. The National Longitudinal Surveys of Youth contain information on an individual's education choice as well as that same person's occupational choice. This data could be used to sort out some of the issues raised in this paper. Overall, our findings reinforce that additional research is needed to examine differences in opportunities and how they may affect the wage gap among blacks and whites.

\section{Acknowledgments}

We thank Yuliana Sameroynina and Lisa Efuni for their assistance with the data. We also thank seminar participants at the University of Alberta and the SOLE 2009 Annual Meetings for helpful comments and feedback. 


\section{References}

Alliance for Excellent Education. 2008. African American Students and U.S. High Schools. http://www.all4ed.org/files/archive/publications/AfAm_FactSheet.pdf

Anderson, D. and D. Shapiro. 1996. Racial Differences in Access to High-Paying Jobs and the Wage Gap Between Black and White Women. Industrial and Labor Relations Review 49(2), (January): 273-286.

Auerbach, D. I., P. I. Buerhaus, and D. O. Staiger. 2007. Better late than Never: Workforce Supply Implications of Later Entry into Nursing. Health Affairs 26, (January/February): 178-185.

Beblo, M., D. Beninger, A. Heinze, and F. Laisney. 2003. Measuring Selectivity-Corrected Gender Wage Gaps in the EU. ZEW Discussion Papers No. 03-74.

Becker, G. S. and B. R. Chiswick.1966. The Economics of Education and the Distribution of Earnings. American Economic Review 56 (March): 358-369.

Black, D., A. Haviland, S. Sanders, and L. Taylor. 2006. Why Do Minority Men Earn Less? A Study of Wage Differentials Among the Highly Educated." Review of Economics and Statistics 88(1): 300-313.

Black, D., A. Haviland, S. Sanders, and L. Taylor. 2008. Gender Wage Disparities Among the Highly Educated" The Journal of Human Resources 43(1): 630-659.

Black, S. and A. Sufi. 2002. Who Goes to College? Differential Enrollment by Race and Family Background. National Bureau of Economic Research Working Paper No. 9310.

Blinder, A. S. 1973. Wage Discrimination: Reduced Form and Structural Estimates. The Journal of Human Resources 8 No.4 (Fall): 436-455.

Bollinger, C. R. 2003. Measurement Error in Human Capital and the Black-White Wage Gap. 
The Review of Economics and Statistics 85 (August): 578-585.

Caldwell Jr., R. 2009. The Effects of University Affirmative Action Policies on Human Capital Development of Minority Children: Do Expectations Matter? Unpublished manuscript, Department of Economics, University of Kansas, Lawrence.

Cameron, S. V. and J. J. Heckman. 2001. The Dynamics of Educational Attainment for Black, Hispanic, and White Males. Journal of Political Economy 109 (June): 455-499.

Carneiro, P., and J. J. Heckman. 2003. Human Capital Policy. National Bureau of Economic Research Working Paper No.9495.

Chiswick, B. R. 1988. Differences in Education and Earnings Across Racial and Ethnic Groups: Tastes, Discrimination and Investment in Child Quality. Quarterly Journal of Economics 103 (August): 571-597.

The Journal of Blacks in Higher Education. 1997. The Effect of Higher Education on Interracial Marriage. 16: 55-56.

Gould, E. D., and M. Daniele Paserman. 2003. Waiting for Mr. Right: Rising Inequality and Declining Marriage Rates. Journal of Urban Economics 53: 257-281.

Gullickson, A.. 2006. Education and Black -White Interracial Marriage. Demography 43 (November): 673-689.

Heckman, J. J. 1979. Sample selection bias as a specification error. Econometrica 47 (January): $153-161$.

Houseworth, C. A. 2008. Human Capital and Interracial Marriage in the United States. Unpublished Manuscript.

Jacobsen, J., C. Olsen, J. King Rice, S. Sweetland, and J. Ralph. 2001. Educational Attainment and Black-White Inequality. National Center for Education Statistics: Statistical Analysis 
Report (July).

Jones, C. Bland, and M. Gates. 2004. Gender-Based Wage Differentials in a Predominantly Female Profession: Observations from Nursing. Economics of Education Review 23(6) (December): 615-631.

Lichter, D., F. LeClere, and D. McLaughlin. 1991. Local Marriage Markets and the Marital Behavior of Black and White Women. American Journal of Sociology 96(4) (January): 843-867.

Linsenmeier, D., M., H. S. Rosen, and C. Elena Rouse. 2002. Financial Aid Packages and College Enrollment Decisions: An Econometric Case Study National Bureau of Economic Research Working Paper No 9228.

Neal, D. A. 2004. The Measured Black-White Wage Gap among Women Is Too Small. Journal of Political Economy 112 (February): 1-28.

Neal, D. A. and W. R. Johnson. 1996. The Role of Premarket Factors in Black-White Wage Differences. The Journal of Political Economy 104 (October): 869-895.

Oaxaca, R.. 1973. Male-Female Wage Differentials in Urban Labor Markets. International Economic Review 14 (October): 693-709.

O’Neill, J., and D. O’Neill. 2005. What do Wage Differentials tell us about Labor Market Discrimination? NBER Working Paper 11240.

Qian, Z..1997. Breaking the Racial Barriers: Variations in Interracial marriage Between 1980 and 1990. Demography 34 (May): 263-276.

Orfield, G., and C. Lee. 2005. Why Segregation Matters: Poverty and Educational Inequality. Harvard Civil Rights Project.

Seitz, S., 2009. Accounting for Racial Differences in Marriage and Employment. Journal of 
Labor Economics 27(3): 385-437. 4 (May): 263-276.

Urzua, S. 2008. Racial Labor Market Gaps The Role of Abilities and Schooling Choices. The Journal of Human Resources 43(4): 919-971.

Veneri, C. M. 1999. Can Occupational Labor Shortages be Identified using Available Data? Monthly Labor Review (March): 15-21. 
Table 1: Mean and Median Black-White Female Nursing Wage Gap

\begin{tabular}{lrr}
\hline & Mean Wage & Median \\
Race & 29.37 & Wage \\
\hline Black $(\mathrm{n}=1,147)$ & 27.06 & 25.20 \\
White $(\mathrm{n}=22,375)$ & $\mathbf{1 . 0 9}$ & $\mathbf{1 . 0 9}$ \\
Wage Gap (Black/White) &
\end{tabular}

\section{By education}

\begin{tabular}{lrr}
\multicolumn{2}{c}{ Mean Wage } & Median \\
Associate's Degree or Diploma & & \\
Black & 27.80 & 25.94 \\
White & 25.32 & 23.55 \\
Wage Gap & $\mathbf{1 . 1 0}$ & $\mathbf{1 . 1 0}$ \\
Bachelor's Degree & & \\
Black & 29.32 & 27.78 \\
White & 27.05 & 25.00 \\
Wage Gap & $\mathbf{1 . 0 8}$ & $\mathbf{1 . 1 1}$ \\
Graduate Degree & & \\
Black & 34.61 & 31.16 \\
White & 33.81 & 31.25 \\
Wage Gap & $\mathbf{1 . 0 2}$ & $\mathbf{1 . 0 0}$ \\
\hline
\end{tabular}

Source - National Sample Survey of Registered Nurses, 2004

Notes: Only includes those employed in nursing at the time of the survey. A Diploma degree is a 3-year degree program run by a hospital. The wage gap is calculated as the ratio of black wages to white wages. 
Table 2: Labor Force Participation Rates for Female Registered Nurses by Race and Family Structure

\begin{tabular}{|c|c|c|c|c|c|}
\hline \multirow[b]{2}{*}{ Labor Force Status } & \multirow[b]{2}{*}{ All } & \multicolumn{2}{|c|}{$\begin{array}{c}\text { Children under age } \\
18 \text { in Home }\end{array}$} & \multicolumn{2}{|c|}{$\begin{array}{l}\text { No Children under } \\
\text { age } 18 \text { in home }\end{array}$} \\
\hline & & Married & Not Married & Married & Not Married \\
\hline Black (number of observations; \% of total) & 1,301 & $34.82 \%$ & $16.60 \%$ & $21.75 \%$ & $26.83 \%$ \\
\hline Employed in Nursing & $77.79 \%$ & $80.13 \%$ & $78.24 \%$ & $74.56 \%$ & $77.08 \%$ \\
\hline Employed Outside of Nursing & $5.23 \%$ & $4.19 \%$ & $3.24 \%$ & $6.01 \%$ & $7.16 \%$ \\
\hline Unemployed but Looking for a Nursing Job & $11.15 \%$ & $10.82 \%$ & $12.96 \%$ & $10.60 \%$ & $10.89 \%$ \\
\hline Not in Labor Force & $5.84 \%$ & $4.86 \%$ & $5.56 \%$ & $8.83 \%$ & $4.87 \%$ \\
\hline White (number of observations; \% of total) & 26,108 & $39.23 \%$ & $18.75 \%$ & $34.91 \%$ & $7.11 \%$ \\
\hline Employed in Nursing & $77.21 \%$ & $78.95 \%$ & $75.86 \%$ & $75.29 \%$ & $80.60 \%$ \\
\hline Employed Outside of Nursing & $7.63 \%$ & $6.69 \%$ & $8.23 \%$ & $8.55 \%$ & $6.68 \%$ \\
\hline Unemployed but Looking for a Nursing Job & $6.64 \%$ & $6.17 \%$ & $9.07 \%$ & $5.40 \%$ & $8.89 \%$ \\
\hline Not in Labor Force & $8.53 \%$ & $8.19 \%$ & $6.84 \%$ & $10.76 \%$ & $3.83 \%$ \\
\hline
\end{tabular}

Source - National Sample Survey of Registered Nurses, 2004 
Table 3: Descriptive Statistics by Race

\begin{tabular}{|c|c|c|}
\hline Variable Name & $\begin{array}{r}\text { Black } \\
\text { Females } \\
\end{array}$ & $\begin{array}{r}\text { White } \\
\text { Females }\end{array}$ \\
\hline Family Resources used to pay for R.N. education & 0.290 & 0.488 \\
\hline Experience & 15.178 & 16.571 \\
\hline \multicolumn{3}{|l|}{ Marital Status } \\
\hline Married & 0.566 & 0.741 \\
\hline Single & 0.178 & 0.082 \\
\hline Divorced/Separated/Widowed & 0.257 & 0.177 \\
\hline \multicolumn{3}{|l|}{ Child in home } \\
\hline Youngest Child in Home Under Age 6 & 0.167 & 0.159 \\
\hline Youngest Child in Home Age 6-17 & 0.347 & 0.304 \\
\hline No child under age 18 in home & 0.486 & 0.537 \\
\hline \multicolumn{3}{|l|}{ Highest Nursing Education } \\
\hline Associate & 0.377 & 0.352 \\
\hline Diploma & 0.096 & 0.163 \\
\hline Bachelor & 0.380 & 0.351 \\
\hline Graduate & 0.147 & 0.133 \\
\hline \multicolumn{3}{|l|}{ Region } \\
\hline Northeast & 0.138 & 0.197 \\
\hline West & 0.105 & 0.235 \\
\hline South & 0.620 & 0.304 \\
\hline Midwest & 0.137 & 0.264 \\
\hline \multicolumn{3}{|l|}{ Urban/Rural Status } \\
\hline Rural - Large & 0.062 & 0.122 \\
\hline Rural - Small & 0.027 & 0.065 \\
\hline Rural - Isolated & 0.009 & 0.058 \\
\hline Urban & 0.902 & 0.755 \\
\hline \multicolumn{2}{|l|}{ Mobility } & 0.876 \\
\hline Moved once since becoming $\mathrm{RN}$ & 0.367 & 0.336 \\
\hline Moved more than once since becoming RN & 0.129 & 0.115 \\
\hline Not moved since becoming RN & 0.503 & 0.548 \\
\hline Number of observations & 1,301 & 26,108 \\
\hline
\end{tabular}

Source - National Sample Survey of Registered Nurses, 2004

Notes: Experience equals the number of years the nurse has worked at least half the year since receiving $\mathrm{RN}$ license. A Diploma degree is a 3year degree program run by a hospital. 
Table 4: Ordinary Least Squares - Log Wage Results for Registered Nurses by Race

\begin{tabular}{|c|c|c|c|c|c|c|}
\hline \multirow{4}{*}{$\begin{array}{l}\text { Variable Name } \\
\text { Family Resources used to pay for education } \\
\text { Experience }\end{array}$} & \multicolumn{3}{|c|}{ Black } & \multicolumn{3}{|c|}{ White } \\
\hline & Coef. & Std. Err. & & Coef. & Std. Err. & \\
\hline & 0.054 & 0.028 & $* *$ & -0.002 & 0.006 & \\
\hline & 0.010 & 0.005 & $* *$ & 0.015 & 0.001 & $* *$ \\
\hline Experience $^{2 *} 100$ & -0.018 & 0.013 & & -0.029 & 0.003 & $* *$ \\
\hline Married & 0.016 & 0.033 & & -0.028 & 0.010 & $* *$ \\
\hline Separated & 0.012 & 0.037 & & -0.007 & 0.011 & \\
\hline Youngest Child in Home Under Age 6 & 0.066 & 0.036 & & 0.046 & 0.008 & $* *$ \\
\hline Youngest Child in Home Age 6-17 & 0.008 & 0.028 & & 0.004 & 0.006 & \\
\hline Associate & 0.019 & 0.046 & & -0.010 & 0.009 & \\
\hline Bachelor & 0.058 & 0.045 & & 0.044 & 0.008 & $* *$ \\
\hline Graduate & 0.207 & 0.050 & $* *$ & 0.236 & 0.010 & $* *$ \\
\hline Northeast & 0.199 & 0.047 & $* *$ & 0.133 & 0.008 & $* *$ \\
\hline South & 0.049 & 0.037 & & 0.046 & 0.007 & $* *$ \\
\hline West & 0.146 & 0.050 & $* *$ & 0.115 & 0.008 & $* *$ \\
\hline Rural - Large & -0.191 & 0.050 & $* *$ & -0.111 & 0.008 & $* *$ \\
\hline Rural - Small & -0.322 & 0.077 & $* *$ & -0.131 & 0.011 & $* *$ \\
\hline Rural - Isolated & -0.315 & 0.128 & $* *$ & -0.182 & 0.011 & $* *$ \\
\hline Employed in Nursing One Year Ago & 0.115 & 0.053 & $* *$ & 0.089 & 0.014 & $* *$ \\
\hline Moved once since becoming $\mathrm{RN}$ & 0.014 & 0.027 & & 0.001 & 0.006 & \\
\hline Moved more than once since becoming RN & -0.085 & 0.038 & $* *$ & 0.003 & 0.009 & \\
\hline Constant & 2.947 & 0.079 & $* *$ & 2.912 & 0.019 & $* *$ \\
\hline F-statistic & 7.41 & & & 154.53 & & \\
\hline Adjusted R-squared & 0.962 & & & 0.115 & & \\
\hline Raw Differential & 8.1 & & & & & \\
\hline Portion Due to endowments & 12.2 & & & & & \\
\hline Portion due to coefficients & 87.8 & & & & & \\
\hline
\end{tabular}

Source - National Sample Survey of Registered Nurses, 2004

Notes: Dependent variable is log hourly wage. The omitted categories are: divorced/separated/widowed; no children under age 18 in the home; Diploma degree; Midwest; urban; and, not moved since becoming RN. Experience equals the number of years the nurse has worked at least half the year since receiving $\mathrm{RN}$ license. A Diploma degree is a 3-year degree program run by a hospital.

** indicates that the coefficient is statistically significant at the $5 \%$ level. 
Table 5: Percent of Wage Gap Explained by Observable Characteristics

\begin{tabular}{lr}
\hline Regression Methodology & $\begin{array}{r}\text { Proportion } \\
\text { Explained }\end{array}$ \\
\hline OLS (Table 4) & 12.2 \\
OLS with just family resources & -21.3 \\
OLS with just family resources, education, & \\
marital status, and children & -10.9 \\
& \\
Correcting for Selection into Employment & \\
$\quad$ Heckman Selection & 5.5 \\
Imputing Wages & 9.9 \\
\hline
\end{tabular}

Source - National Sample Survey of Registered Nurses, 2004

Notes: The number represents the proportion of the wage gap explained by the observables in the regression, using the Blinder-Oaxaca decomposition. The OLS results come from Table 4. The Heckman selection results use non-nursing household income as an instrument for labor force participation. To impute wages for those not employed in nursing, we use education, marital status, and children status cells and assign the median of the cell to all women in that cell who do not work in nursing. 
Table 6: Source of Education Financing by Race and Education

\begin{tabular}{|c|c|c|c|c|c|c|c|c|c|}
\hline \multirow[t]{2}{*}{ Source of financing } & \multicolumn{6}{|c|}{$\begin{array}{c}\text { Associate or } \\
\text { Diploma }\end{array}$} & \multicolumn{3}{|c|}{ Bachelor } \\
\hline & Black & White & & Black & White & & Black & White & \\
\hline Loans or scholarships only & $\overline{0.246}$ & $\overline{0.124}$ & $* *$ & $\overline{0.243}$ & $\overline{0.136}$ & $* *$ & $\overline{0.248}$ & $\overline{0.111}$ & $* *$ \\
\hline Self or family only & 0.272 & 0.414 & $* *$ & 0.324 & 0.435 & $* *$ & 0.225 & 0.392 & $* *$ \\
\hline Employer only & 0.025 & 0.013 & $* *$ & 0.036 & 0.017 & $* *$ & 0.016 & 0.008 & $* *$ \\
\hline Multiple sources & 0.457 & 0.449 & & 0.397 & 0.411 & & 0.511 & 0.488 & \\
\hline
\end{tabular}

Source - National Sample Survey of Registered Nurses, 2004

Notes: The question refers to financing the degree that made the nurse eligible to become a registered nurse.

** Indicates Black-White proportions are statistically significantly different at 5\% level. 
Table 7: Descriptive Statistics by Race and Occupation American Community Survey

\begin{tabular}{|c|c|c|c|c|}
\hline \multirow[t]{2}{*}{ Variable name } & \multicolumn{2}{|c|}{ Registered Nurses } & \multicolumn{2}{|c|}{ K-12 Teachers } \\
\hline & $\begin{array}{r}\text { Black } \\
\text { Females }\end{array}$ & $\begin{array}{r}\text { White } \\
\text { Females }\end{array}$ & $\begin{array}{r}\text { Black } \\
\text { Females }\end{array}$ & $\begin{array}{r}\text { White } \\
\text { Females }\end{array}$ \\
\hline $\begin{array}{l}\text { Potential Experience } \\
\text { Marital Status }\end{array}$ & 22.80 & 23.46 & 21.91 & 21.16 \\
\hline Married & 0.54 & 0.73 & 0.54 & 0.75 \\
\hline Single & 0.16 & 0.09 & 0.23 & 0.12 \\
\hline $\begin{array}{r}\text { Divorced/Separated/Widowed } \\
\text { Children in home }\end{array}$ & 0.30 & 0.18 & 0.23 & 0.13 \\
\hline Child under age 6 in home & 0.16 & 0.15 & 0.12 & 0.14 \\
\hline $\begin{array}{l}\text { Child aged } 6-17 \text { in home } \\
\text { No child under age } 18 \text { in } \\
\text { home }\end{array}$ & 0.33 & 0.28 & 0.26 & 0.28 \\
\hline Education & & & & \\
\hline Associate & 0.42 & 0.48 & 0.06 & 0.04 \\
\hline Bachelor & 0.43 & 0.39 & 0.42 & 0.49 \\
\hline Graduate & 0.15 & 0.14 & 0.51 & 0.48 \\
\hline Region & & & & \\
\hline Northeast & 0.18 & 0.22 & 0.14 & 0.22 \\
\hline South & 0.59 & 0.32 & 0.67 & 0.34 \\
\hline West & 0.07 & 0.16 & 0.06 & 0.19 \\
\hline Midwest & 0.16 & 0.30 & 0.13 & 0.26 \\
\hline Number of observations & 365 & 6,594 & 479 & 8,594 \\
\hline
\end{tabular}

Source: American Community Surveys, 2004-2005

Notes: Potential experience equals age minus years of schooling minus six. 
Table 8: Mean and Median Black-White Female Wage Gap by Occupation, American Community Survey

\begin{tabular}{lrr}
\hline Race & $\begin{array}{r}\text { Mean } \\
\text { Wage }\end{array}$ & $\begin{array}{r}\text { Median } \\
\text { Wage }\end{array}$ \\
\hline Registered Nurses & & \\
Black Females $(\mathrm{n}=365)$ & 26.86 & 25.19 \\
White Females $(\mathrm{n}=6,594)$ & 25.41 & 23.37 \\
Wage Gap & $\mathbf{1 . 0 6}$ & $\mathbf{1 . 0 8}$ \\
& & \\
K-12 Teachers & & \\
Black Females $(\mathrm{n}=479)$ & 24.72 & 21.70 \\
White Females $(\mathrm{n}=8,594)$ & 22.49 & 20.36 \\
Wage Gap & $\mathbf{1 . 1 0}$ & $\mathbf{1 . 0 7}$ \\
\hline
\end{tabular}

Source: American Community Surveys, 2004-2005. Notes: For registered nurses, we use occupation code 3130. For K-12 teachers, we use occupation codes 2310 , 2320,2330 , and 2340 . The wage gap is calculated as the ratio of black wages to white wages. 
Table 9: Mean and Median Black-White Female Wage Gap and Employment Gap, American Community Survey

\begin{tabular}{|c|c|c|c|c|}
\hline \multirow{2}{*}{ Race } & \multicolumn{2}{|c|}{ Females } & \multicolumn{2}{|c|}{ Males } \\
\hline & $\begin{array}{r}\text { Median } \\
\text { Wage }\end{array}$ & $\begin{array}{r}\text { Employment } \\
\text { Rate }\end{array}$ & $\begin{array}{r}\text { Median } \\
\text { Wage }\end{array}$ & $\begin{array}{r}\text { Employment } \\
\text { Rate }\end{array}$ \\
\hline Black & 13.49 & 59.84 & 14.92 & 64.77 \\
\hline White & 14.51 & 65.69 & 18.60 & 80.98 \\
\hline Gap & 0.93 & 0.91 & 0.80 & 0.80 \\
\hline \multicolumn{5}{|c|}{ High School Dropout } \\
\hline Black & 8.06 & 31.56 & 10.45 & 39.61 \\
\hline White & 8.76 & 37.52 & 12.09 & 62.54 \\
\hline Gap & 0.92 & 0.84 & 0.86 & 0.63 \\
\hline \multicolumn{5}{|c|}{ High School } \\
\hline Black & 10.23 & 54.31 & 12.86 & 62.76 \\
\hline White & 11.16 & 59.87 & 15.35 & 77.10 \\
\hline Gap & 0.92 & 0.91 & 0.84 & 0.81 \\
\hline \multicolumn{5}{|c|}{ Some College } \\
\hline Black & 13.43 & 67.01 & 15.74 & 71.48 \\
\hline White & 13.95 & 69.39 & 18.60 & 82.37 \\
\hline Gap & 0.96 & 0.97 & 0.85 & 0.87 \\
\hline \multicolumn{5}{|c|}{ Bachelor } \\
\hline Black & 18.60 & 78.87 & 20.46 & 81.80 \\
\hline White & 18.60 & 72.75 & 24.39 & 88.43 \\
\hline Gap & 1.00 & 1.08 & 0.84 & 0.93 \\
\hline \multicolumn{5}{|c|}{ Graduate } \\
\hline Black & 26.14 & 81.44 & 27.41 & 84.36 \\
\hline White & 24.18 & 78.56 & 32.55 & 88.78 \\
\hline Gap & 1.08 & 1.04 & 0.84 & 0.95 \\
\hline
\end{tabular}

Source: American Community Surveys, 2004-2005.

Notes: Sample size for the wage data is: for black females 12,350; for white females, 137,218; for black males, 9,792; and, for white males, 153,099.

The wage gap is calculated as the ratio of black wages to white wages. 
Figure 1: Percent of RNs who are Black and Black/White RN Wage Gap

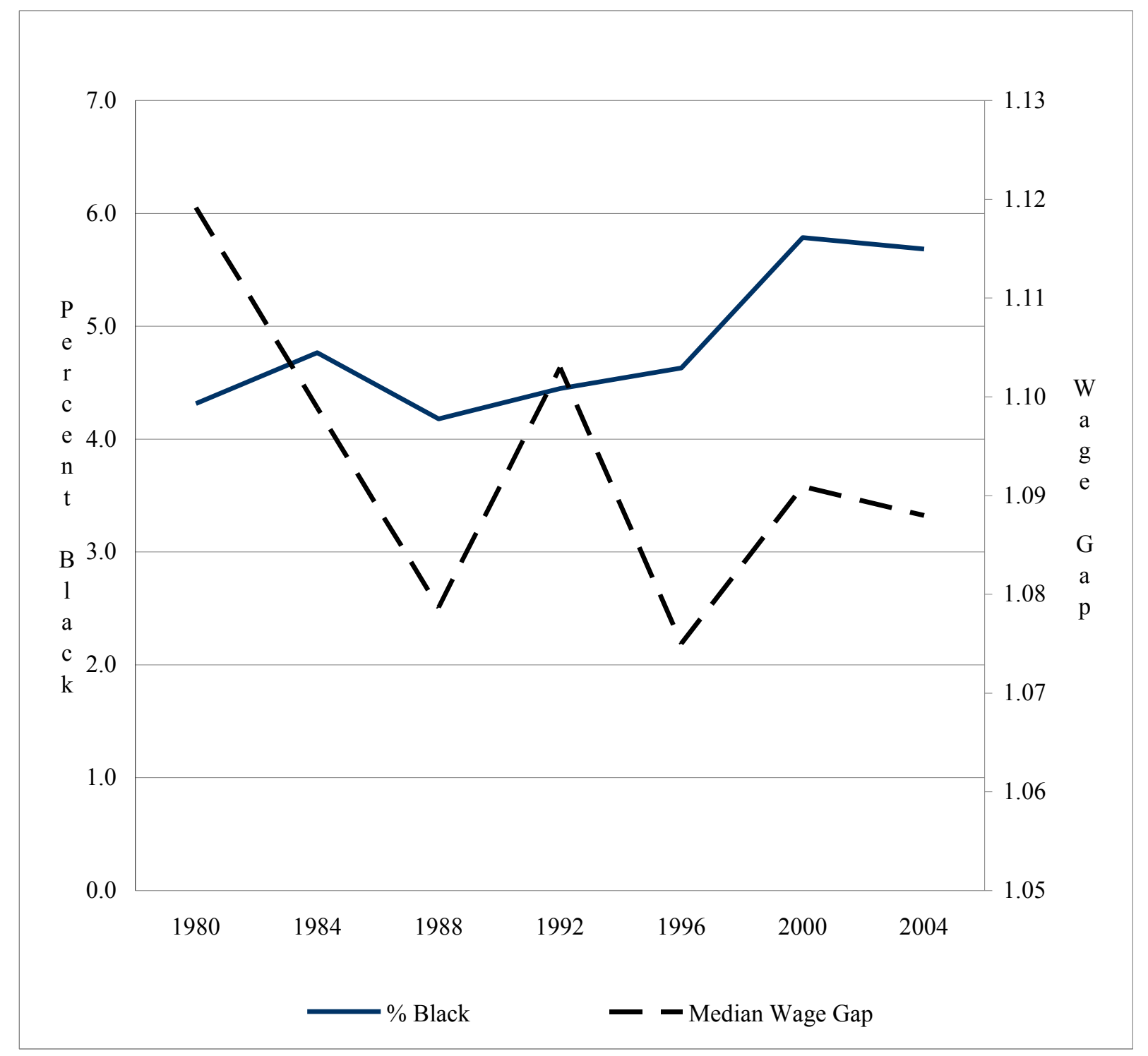

Source: National Sample Survey of Registered Nurses, 1980, 1984, 1988, 1992, 1996, 2000, and 2004

Notes: Sample is restricted to black and white females, employed in nursing at the time of the survey, and with valid earnings, hours worked, weeks worked, education, and age data. 